\title{
Antibodies to SARS-CoV-2 are associated with protection against
}

\section{reinfection}

Sheila F Lumley ${ }^{1,2}$, Denise O'Donnell ${ }^{2}$, Nicole E Stoesser ${ }^{1,2,3,4}$, Philippa C Matthews ${ }^{1,2,3,4}$, Alison Howarth ${ }^{2}$, Stephanie B Hatch ${ }^{2}$, Brian D Marsden ${ }^{2,5}$, Stuart Cox ${ }^{1}$, Tim James $^{1}$, Fiona Warren ${ }^{1}$, Liam J Peck ${ }^{6}$, Thomas G Ritter $^{6}$, Zoe de Toledo ${ }^{6}$, Laura Warren ${ }^{1}$, David Axten ${ }^{1}$, Richard J Cornall ${ }^{2}$, E Yvonne Jones $^{2}$, David I Stuart ${ }^{2}$, Gavin Screaton ${ }^{2}$, Daniel Ebner ${ }^{2,7}$, Sarah Hoosdally ${ }^{2,3,4}$, Meera Chand ${ }^{8}$, Oxford University Hospitals Staff Testing Group, Derrick W Crook ${ }^{2,3,4}$, Anne-Marie O'Donnell ${ }^{1}$, Christopher P Conlon ${ }^{2}$, Koen B Pouwels ${ }^{4,9}$, A Sarah Walker ${ }^{2,3,4}$, Tim EA Peto ${ }^{2,3,4}$, Susan Hopkins ${ }^{8}$, Timothy M Walker ${ }^{2,10}$, Katie Jeffery ${ }^{1}$, David W Eyre $^{3,4,11,12}$

${ }^{1}$ Oxford University Hospitals NHS Foundation Trust, Oxford, UK

${ }^{2}$ Nuffield Department of Medicine, University of Oxford, Oxford, UK

${ }^{3}$ NIHR Oxford Biomedical Research Centre, University of Oxford, Oxford, UK

${ }^{4}$ NIHR Health Protection Research Unit in Healthcare Associated Infections and Antimicrobial Resistance at University of Oxford in partnership with Public Health England, Oxford, UK

${ }^{5}$ Kennedy Institute of Rheumatology Research, University of Oxford, UK

${ }^{6}$ Medical School, University of Oxford, Oxford, UK

${ }^{7}$ Target Discovery Institute, University of Oxford, Oxford, UK

${ }^{8}$ National Infection Service, Public Health England Colindale, UK

${ }^{9}$ Health Economics Research Centre, Nuffield Department of Population Health, University of Oxford, Oxford, UK 
${ }^{10}$ Oxford University Clinical Research Unit, Ho Chi Minh City, Vietnam

${ }^{11}$ Nuffield Department of Population Health, University of Oxford, Oxford, UK

${ }^{12}$ Big Data Institute, University of Oxford, Oxford, UK

\section{Corresponding author:}

David Eyre

david.eyre@bdi.ox.ac.uk

$+44(0) 1865221081$

Microbiology Department, John Radcliffe Hospital, Headley Way, Oxford, OX3 9DU

\section{Keywords:}

SARS-CoV-2; Covid-19; serology; antibody; longitudinal; reinfection; immunity

\section{Oxford University Hospitals Staff Testing Group:}

\section{University of Oxford Medical School staff testing team (University of Oxford, Oxford, UK): Molly}

Abbott, Roxanna Abhari, Hibatullah Abuelgasim, Tariq Ahmed-Firani, Ahmed Alhussni, Isobel Argles,

Rebecca Ashworth, Francesca Back, Susannah Black, Isabelle Brennan, Helen Callard, Lottie Cansdale, Triya Chakravorty, Magdalena Chmura, Zahra Choudhury, Helen Clay, Rebecca Conway-Jones, Aisling Curtis, Joseph Cutteridge, Hannah Danbury, Hettie Davies, Lucy Denly, Julie Dequaire, Stoyan Dimitrov, Ella Dunlop, Polly Dunn, Cameron East, Ben Eastwood, Chantal Edwardes, Meirian Evans, Charlotte Fields, Sarah Flaherty, Thomas Foord, Rosie Freer, Hannah Fuchs, Alexander Grassam-Rowe, Lewis Greenan-Barrett, James Gunnell, Callum Harries, Edward Harris, Elizabeth Hatton, Conor Hennesey, 
medRxiv preprint doi: https://doi.org/10.1101/2020.11.18.20234369; this version posted November 19, 2020. The copyright holder for this preprint (which was not certified by peer review) is the author/funder, who has granted medRxiv a license to display the preprint in perpetuity.

It is made available under a CC-BY 4.0 International license .

Christian Holland, Ben Holloway, Gregory Howgego, Isaac Jarratt Barnham, Síle Johnson, Thomas Johnson, Daniela Johnstone, Julia Johnstone, Rebecca Jurdon, Gabriella Kelly, Sven Kerneis, Beinn Khulusi, Annabel Killen, Stefan Kourdov, Mary Kumarendran, Hannah Laurenson-Schafer, Ruby Lawrence, Charlotte Lee, Angus Livingstone, Rosie Lynch, Tara Madsen, Ali Manji, James Marsh, Chris Mason, Angus Mccance, Euan Mcgivern, Ailsa Mckinlay, Alexandra Mighiu, Lancelot Millar, Yethrib Mohamed, Kenzo Motohashi, San Myat, Andrey Nezhentsev, Katherine O'Byrne, Temitope Okuwoga, Madeleine Oliver, Saxon Pattenden, Vimukthi Perera, Yva Petit, Florence Pickles, Maria Pikoula, Govind Randhawa, Krupa Ravi, Lara Reed, Caitlin Rigler, Charlotte Robinson, Evie Rothwell, Stephanie SantosPaulo, Constantinos Savva, Alice Scharmeli, Samuel Scott, Zamin Shabir, Ishta Sharma, Remarez Sheehan, Afrah Shibu, Arun Somanathan, Samuel Sussmes, Owen Sweeney, Emily Swift, Gayatri Tadikamalla, Morwenna Tamblyn, Adan Taylor, Rebecca Te Water Naudé, Sarah Thomas, Connor Thompson, Lottie Till, Ross Toward, Charis Virgo, Imogen Vorley, Seren Waite, Harry Ward, Jocelyn Ward, Adam Watson, Lily Watson, Matthew Wedlich, Esme Weeks, Laura Wilkins, Jack Wilson, Joseph Wilson, William Wong, Rebecca Young

University of Oxford staff testing team (University of Oxford, Oxford, UK): Kevin K Chau, Thomas Christott, George Doherty, Philip W Fowler, Fredrik Karpe, James Kavanagh, Lucas Martins Ferreira, Matt J Neville, Hayleah Pickford, Gillian Rodger, Donal Skelly, Jeremy Swann, Phoebe Tamblin-Hopper, Denis Volk, Fan Yang-Turner

\section{Oxford University Hospitals staff testing team (Oxford University Hospitals NHS Foundation Trust,}

Oxford, UK): Ali Amini, Monique Andersson, Karen Anson, Lisa Aston, Simran Barot, Trisha Bellinger, Adrian Bialek, Noemi Bodo, Andrew Brent, Mark Campbell, Vanessa Cox, Victoria Cox, Tammy Cronin, Timothy Davies, Alessio Deales, Louise Downs, Philip Drennan, Maria Dudareva, Laura Gates, Michelle 
medRxiv preprint doi: https://doi.org/10.1101/2020.11.18.20234369; this version posted November 19, 2020. The copyright holder for this preprint (which was not certified by peer review) is the author/funder, who has granted medRxiv a license to display the preprint in perpetuity. It is made available under a CC-BY 4.0 International license .

Gates, Dominique Georgiou, Bernadett Gergely, Louise Holland, Nicola Jones, Sarah Jones, Sharon Kerr, Elaine Lawson, Stacy Looms, Michael Luciw, Diva Martins, Mary Mcknight, Alexander Mentzer, Rebecca Millard, Tracey Mitchell, Lisa Morgan, Jordan Morrow, Emma Mortimore, Harriet Mullins, Heather Nevard, Kaisha Patel, Leon Peto, Jane Philips, Jessica Ponting, Roshni Ray, Maria Robles, Sonam Rughani, Nellia Sande, Angelo Scheller, Robert Shaw, Emma-Jane Simons, Elizabeth Sims, Kyla Smit, Lucianne Smith, Justyna Szczurkowska, Zoe Thompson, Rachel Turford, Kim Vilca, Alexander Vogt, Annie Westlake, Vicki Wharton, Alison Whitty, Heather Woodley, Barbara Wozniak, Bernadette Young

\section{Oxford University Hospitals microbiology laboratory (Oxford University Hospitals NHS Foundation}

Trust, Oxford, UK): Kathryn Cann, Mohamad Fadzillah, Nurul Huda, Anita Justice, Richard Kirton, Gerald Jesuthasan, Susan Wareing

Oxford University Hospitals Infection, Prevention and Control team (Oxford University Hospitals NHS

Foundation Trust, Oxford, UK): Lisa Butcher, Gabriella D'Amato, Ruth Moroney, Gemma Pill, Lydia Rylance-Knight, Claire Sutton, Claudia Salvagno, Merline Tabirao, Sarah Wright 


\section{Abstract}

\section{Background}

It is critical to understand whether infection with Severe Acute Respiratory Syndrome Coronavirus 2 (SARS-CoV-2) protects from subsequent reinfection.

\section{Methods}

We investigated the incidence of SARS-CoV-2 PCR-positive results in seropositive and seronegative healthcare workers (HCWs) attending asymptomatic and symptomatic staff testing at Oxford University Hospitals, UK. Baseline antibody status was determined using anti-spike and/or anti-nucleocapsid IgG assays and staff followed for up to 30 weeks. We used Poisson regression to estimate the relative incidence of PCR-positive results and new symptomatic infection by antibody status, accounting for age, gender and changes in incidence over time.

\section{Results}

A total of 12219 HCWs participated and had anti-spike IgG measured, 11052 were followed up after negative and 1246 after positive antibody results including 79 who seroconverted during follow up. 89 PCR-confirmed symptomatic infections occurred in seronegative individuals ( 0.46 cases per 10,000 days at risk) and no symptomatic infections in those with anti-spike antibodies. Additionally, 76 (0.40/10,000 days at risk) anti-spike lgG seronegative individuals had PCR-positive tests in asymptomatic screening, compared to $3(0.21 / 10,000$ days at risk) seropositive individuals. Overall, positive baseline anti-spike antibodies were associated with lower rates of PCR-positivity (with or without symptoms) (adjusted rate ratio $0.24[95 \% \mathrm{Cl} 0.08-0.76, \mathrm{p}=0.015])$. Rate ratios were similar using anti-nucleocapsid IgG alone or combined with anti-spike IgG to determine baseline status. 
medRxiv preprint doi: https://doi.org/10.1101/2020.11.18.20234369; this version posted November 19, 2020. The copyright holder for this preprint (which was not certified by peer review) is the author/funder, who has granted medRxiv a license to display the preprint in perpetuity.

It is made available under a CC-BY 4.0 International license .

\section{Conclusions}

Prior SARS-CoV-2 infection that generated antibody responses offered protection from reinfection for most people in the six months following infection. Further work is required to determine the long-term duration and correlates of post-infection immunity. 
medRxiv preprint doi: https://doi.org/10.1101/2020.11.18.20234369; this version posted November 19, 2020. The copyright holder for this preprint (which was not certified by peer review) is the author/funder, who has granted medRxiv a license to display the preprint in perpetuity.

It is made available under a CC-BY 4.0 International license.

\section{Introduction}

SARS-CoV-2 infection produces detectable immune responses in most cases reported to date; however, it is uncertain whether previously infected people are protected from a second infection. Understanding whether post-infection immunity exists, how long it lasts, and the extent to which it may prevent, or reduce the severity of symptomatic reinfection, has major implications for the future of the SARS-CoV-2 pandemic and the corresponding global public health response.

Post-infection immunity may be conferred by various humoral and cell-mediated immune responses. Key considerations when investigating post-infection immunity include identifying functional correlates of protection, identifying surrogate tests (usually antibody assays) as markers that may not be protective in themselves but act as a proxy for protection, and defining the end-points of interest e.g. prevention of reinfection, disease, hospitalisation, death or onward-transmission. ${ }^{1}$

The assay-dependent antibody dynamics of SARS-CoV-2 anti-spike and anti-nucleocapsid antibodies are beginning to be defined. ${ }^{2-6}$ Neutralising antibodies against the receptor-binding domain of the spike protein may provide some post-infection immunity; however, this has yet to be demonstrated in longitudinal studies. Additionally, the association between antibody titres and plasma neutralising activity is assay-dependent and becomes weaker over time. ${ }^{7-10}$

Evidence for post-infection immunity is emerging. Despite an estimated 55 million people infected worldwide and high rates of ongoing transmission, reports of SARS-CoV-2 reinfection are few, mostly in individuals with mild or asymptomatic primary infection. ${ }^{11-20}$ Although a lack of widely-available PCR testing early in the pandemic may limit the numbers of confirmed reinfections reported, this suggests that infection with SARS-CoV-2 provides some protective immunity against reinfection in most people. 
medRxiv preprint doi: https://doi.org/10.1101/2020.11.18.20234369; this version posted November 19, 2020. The copyright holder for this preprint (which was not certified by peer review) is the author/funder, who has granted medRxiv a license to display the preprint in perpetuity.

It is made available under a CC-BY 4.0 International license .

However no prospective longitudinal studies have yet compared infection rates in seropositive and seronegative individuals, however there are some small-scale reports that suggest antibodies may be associated with protection against infection. ${ }^{21}$

Here we present follow-up from a prospective longitudinal cohort study of healthcare workers (HCWs) at Oxford University Hospitals (OUH). Comparing the incidence of PCR-positive results and symptomatic infection in seropositive versus seronegative HCWs during up to 30 weeks of follow-up demonstrates post-infection immunity lasting at least 6 months.

\section{Methods}

\section{Cohort description}

OUH offers both symptomatic and asymptomatic SARS-CoV-2 staff testing programs, defining a HCW as anyone working at its four teaching hospital sites in Oxfordshire, UK.

SARS-CoV-2 PCR testing of nasal and oropharyngeal swabs for all symptomatic (new persistent cough, fever $\geq 37.8^{\circ} \mathrm{C}$, anosmia/ageusia) staff was offered from 27-March-2020 onwards. PCR-positive results from community-based symptomatic testing of OUH HCWs forwarded by public health agencies were also included.

Asymptomatic HCWs were invited to participate in voluntary SARS-CoV-2 testing by nasal and oropharyngeal swab PCR and serological testing from 23-April-2020 onwards. The cohort, associated methods, baseline and 6-month antibody trajectory findings have been previously described., ${ }^{52-24}$ Following initial PCR and antibody testing, asymptomatic HCWs were invited to optionally attend for 
medRxiv preprint doi: https://doi.org/10.1101/2020.11.18.20234369; this version posted November 19, 2020. The copyright holder for this preprint (which was not certified by peer review) is the author/funder, who has granted medRxiv a license to display the preprint in perpetuity.

It is made available under a CC-BY 4.0 International license .

serological testing once every two months, with some offered more frequent screening as part of related studies. Asymptomatic staff were also offered optional SARS-CoV-2 PCR tests every two weeks.

\section{Laboratory assays}

Serological investigations were performed using an enzyme-linked immunosorbent assay platform developed by the University of Oxford detecting IgG to SARS-CoV-2 trimeric spike antigen, using netnormalised signal cut-off of $\geq 8$ million to determine antibody presence. ${ }^{23,24}$ Additional serology for lgG to nucleocapsid protein was performed using the Abbott Architect i2000 chemiluminescent microparticle immunoassay (Abbott, Maidenhead, UK). Antibody levels $\geq 1.40$ arbitrary units were considered positive. PCR testing was performed on a range of platforms (see Supplementary Material).

\section{Statistical analysis}

We classified HCWs according to their baseline antibody status. Those with only negative antibody tests, were considered at risk of infection from their first (negative) antibody test until the earlier of the study end (18-November-2020) or their first PCR-positive test. Those with a positive antibody test were considered at risk of (re)infection from 60 days after their first positive antibody result, to the earlier of study end or their next PCR-positive test, irrespective of subsequent sero-reversion, i.e. any later negative antibody test. The 60 day window was pre-specified to exclude PCR-positive tests due to RNA persistence from the index infection that led to seroconversion (based on earlier observations that RNA persistence could last for $\geq 6$ weeks ${ }^{25,26}$ ). For the same reason, we also only considered PCR-positive tests occurring $\geq 60$ days after the previous PCR-positive test. Those who were initially antibody-negative and then seroconverted were allowed to contribute to the analysis twice; once while at risk of infection and antibody-negative and then subsequently while antibody-positive. 
medRxiv preprint doi: https://doi.org/10.1101/2020.11.18.20234369; this version posted November 19, 2020. The copyright holder for this preprint (which was not certified by peer review) is the author/funder, who has granted medRxiv a license to display the preprint in perpetuity.

It is made available under a CC-BY 4.0 International license .

We used Poisson regression to model incidence of PCR-positive infection per day at risk by baseline antibody status. Models adjusted for changes in overall incidence by including calendar month at risk as a categorical or calendar time as continuous variable (allowing for non-linear effects using natural cubic splines with up to 5 knots, at default positions, and choosing the final number of knots based on the best model fit using the Akaike information criterion). Additionally, we adjusted for age (allowing for non-linear effects similarly) and self-reported gender. We also fitted models considering baseline antibody titre instead of binary antibody status, using allowing for non-linear effects as above. Robust standard errors were used to account for some individuals contributing to the analysis twice, i.e. before and after seroconversion.

Primary analyses used anti-trimeric spike IgG assay results as these were expected a priori to relate most closely to neutralising activity and protection from infection. ${ }^{7,10}$ We also conducted two secondary analyses, considering anti-nucleocapsid antibodies and also a combined model where we allowed individuals to have one of three baseline antibody statuses (both assays negative, both positive, only one positive). Finally, we conducted a sensitivity analysis to investigate the impact of different asymptomatic testing rates by antibody status (see Supplementary Materials).

\section{Ethics statement}

Deidentified data from staff testing were obtained from the Infections in Oxfordshire Research Database (IORD) which has generic Research Ethics Committee, Health Research Authority and Confidentiality Advisory Group approvals (19/SC/0403, 19/CAG/0144). 
medRxiv preprint doi: https://doi.org/10.1101/2020.11.18.20234369; this version posted November 19, 2020. The copyright holder for this preprint (which was not certified by peer review) is the author/funder, who has granted medRxiv a license to display the preprint in perpetuity.

It is made available under a CC-BY 4.0 International license .

\section{Results}

12219 HCWs had baseline anti-spike antibodies measured and were followed up between 23-April and 18-November-2020. 11052 (90.4\%) HCWs were seronegative and 1167 (9.6\%) were seropositive at their first anti-trimeric spike IgG measurement; 79 HCWs seroconverted during the study (Table 1, Figure S1). The median (IQR) [range] age was 38 (29-49) [16-86] years. Individuals were followed for a median (IQR) [range] 188 (174-195) [1-209] days after a negative antibody test and 127 (106-135) [1-149] days after a positive antibody test (starting the "at risk" period 60 days post positive-PCR/serology in seropositive individuals).

Rates of symptomatic PCR testing were similar in seronegative and seropositive HCWs: 1597 PCR tests during $1,908,816$ person-days of follow-up (8.4/10,000 person-days) and 106 during 143,022 persondays $(7.4 / 10,000$ person-days) respectively (rate ratio 0.90 [95\% Cl 0.74-1.09, $\mathrm{p}=0.27]$ ). $8339 \mathrm{HCWs}$ attended for $\geq 1$ asymptomatic screen; seronegative HCWs attended for asymptomatic screening more frequently, (26,153 tests; $138 / 10,000$ person-days), than seropositive staff (1442 tests; 102/10,000 person-days) (rate ratio $0.74[95 \% \mathrm{Cl} 0.70-0.78, \mathrm{p}<0.001])$.

Incidence of PCR positivity by baseline anti-spike IgG antibody status 165/11052 (1.5\%) HCWs were PCR-positive while anti-spike IgG seronegative, 76 during asymptomatic screening and 89 while symptomatic. 3/1246 (0.2\%) HCWs were PCR-positive following a positive antispike IgG measurement, all were asymptomatic. Allowing for the varying duration of follow-up, rates of new PCR-positive results were 0.86 and $0.21 / 10,000$ days-at-risk in seronegative and seropositive HCWs respectively (incidence rate ratio, IRR, $0.24[95 \% \mathrm{Cl} 0.08-0.76, \mathrm{p}=0.015]$ ). No antibody-positive individual had a subsequent symptomatic infection; rates of new PCR-confirmed symptomatic infection were 0.46 and $0.00 / 10,000$ days-at-risk in seronegative and seropositive individuals respectively. 
medRxiv preprint doi: https://doi.org/10.1101/2020.11.18.20234369; this version posted November 19, 2020. The copyright holder for this preprint (which was not certified by peer review) is the author/funder, who has granted medRxiv a license to display the preprint in perpetuity.

It is made available under a CC-BY 4.0 International license.

Incidence of PCR-positive results varied by calendar time (Figure 1A), reflecting the first and second waves of the pandemic, but was consistently higher in the seronegative versus seropositive group. Adjusting for age, gender and for changes in incidence by month, the IRR for being seropositive was 0.25 (95\% $\mathrm{Cl} 0.08-0.80, \mathrm{p}=0.019)$ (Table 2 ) and adjusting for time as a continuous variable, 0.26 (95\% $\mathrm{Cl} 0.08$ $0.81, p=0.020$ ) (Figure $1 B$ ). As rates of asymptomatic testing varied by antibody status, we performed a sensitivity analysis, randomly removing PCR results for seronegative HCWs to match testing rates in seropositive HCWs, yielding an adjusted IRR of 0.28 (95\% CI 0.09-0.90, p=0.032).

Incidence of PCR positivity by baseline antibody titre In addition to the categorical antibody result, we analysed numerical anti-spike IgG titres. Adjusting for month of testing, age and gender, the estimated incidence of PCR-positive results started to fall from titres of $\sim 4$ million and above (cf. threshold for "detection" of 8 million ${ }^{23}$ ) (Figure 2A).

\section{Secondary analyses using anti-nucleocapsid IgG}

We conducted two secondary analyses. Firstly, using anti-nucleocapsid instead of anti-spike antibody measurements as a marker for prior infection ( $n=12453$ HCWs; Figure S1 and Table S1). 169/11336 (0.88/10,000 person-days) seronegative HCWs tested PCR-positive compared to 3/1162 $(0.21 / 10,000$ person-days) antibody-positive HCWs. Accounting for time at risk, age, gender and calendar month, the adjusted IRR for those antibody-positive was 0.26 (95\% Cl 0.08-0.81, $\mathrm{p}=0.021$, Table S2). There was marginal evidence that the incidence of PCR-positive results fell with increasing anti-nucleocapsid antibody titres (IRR per unit increase 0.82 [95\% Cl 0.65-1.03, p=0.08], Figure 2B). 
medRxiv preprint doi: https://doi.org/10.1101/2020.11.18.20234369; this version posted November 19, 2020. The copyright holder for this preprint (which was not certified by peer review) is the author/funder, who has granted medRxiv a license to display the preprint in perpetuity.

It is made available under a CC-BY 4.0 International license .

Second, we classified the $12153 \mathrm{HCWs}$ with available anti-spike and anti-nucleocapsid baseline results, as both assays negative, both positive, or only one positive (Figure S1, Tables S3 and S4). 160/10866

$(0.85 / 10,000$ person-days $)$ of those with two negative assays had subsequent PCR-positive tests, versus $2 / 1015(0.16 / 10,000$ person-days $)$ with both baseline assays positive and $2 / 333(0.55 / 10,000$ persondays) with mixed antibody results. There were reduced rates of subsequent PCR-positive tests in those where both antibody tests were positive compared to both negative, adjusting for age, gender and calendar month, IRR 0.20 (95\% Cl 0.05-0.81, p=0.024), but an absence of evidence in those with mixed results, adjusted IRR $0.67(0.16-2.71, \mathrm{p}=0.57)$.

\section{Description of seropositive individuals with subsequent PCR-positive results}

Four seropositive HCWs subsequently tested PCR-positive (three with anti-spike IgG, two of whom had anti-nucleocapsid IgG, and one additional with anti-nucleocapsid IgG only) (Figure 3 and Table S5).

HCW1 was seropositive for anti-nucleocapsid IgG when first tested in May (original sample retrieved and re-tested, confirmed positive), but seronegative for anti-spike IgG. They had no history of prior Covid-19like symptoms and no prior positive PCR. They developed a febrile illness 160 days later confirmed as Covid-19 by PCR.

HCW2 presented with Covid-19-like symptoms in April and was PCR-positive; they seroconverted with positive anti-spike and anti-nucleocapsid antibodies and remained antibody positive on both assays up to October. They had 5 negative PCRs before becoming PCR-positive again at day 190, diagnosed through asymptomatic staff testing and could not recall any symptoms in retrospect. Repeat PCR tests performed 2 and 4 days later were negative. 
medRxiv preprint doi: https://doi.org/10.1101/2020.11.18.20234369; this version posted November 19, 2020. The copyright holder for this preprint (which was not certified by peer review) is the author/funder, who has granted medRxiv a license to display the preprint in perpetuity.

It is made available under a CC-BY 4.0 International license .

HCW3 reported a febrile illness in mid-February and was not tested for SARS-CoV-2 at the time. They were seropositive for anti-spike, but not anti-nucleocapsid antibodies in May. Three subsequent antibody tests between July and October were negative for both antibodies, with evidence of waning anti-spike titres and persistent low anti-nucleocapsid titres (Figure 3). They regularly attended asymptomatic screening, and had 14 negative PCRs, becoming PCR-positive 180 days following their first serological test. They were asymptomatic when tested, but reported transient myalgia following an influenza vaccine the previous week. Repeat PCR 2 days later was positive.

HCW 4 developed fever and anosmia in March but did not have PCR test. They were seropositive for anti-spike and anti-nucleocapsid antibodies when first tested in May. They tested PCR-positive, whilst asymptomatic, 231 days following initial symptoms.

\section{Discussion}

Virus-specific antibodies are usually recognised as correlates or surrogates of antiviral immunity. Here we describe the results of over 2 million person-days of follow-up, from $11052 \mathrm{HCWs}$ following negative serology, and 1246 following a positive anti-spike antibody test. We show in our primary analysis, that evidence of previous SARS-CoV-2 infection, defined by presence of anti-spike antibodies, is associated with lower risk of a repeat PCR-positive test (IRR $0.24[95 \% \mathrm{Cl} 0.08-0.76, \mathrm{p}=0.015]$ ). No symptomatic infections and only three asymptomatic PCR-positive results were seen in those with anti-spike antibodies, over 30 weeks of follow-up. This suggests that antibodies produced by prior SARS-CoV-2 infection are associated with protection from reinfection for most people for at least six months. Evidence of post-infection immunity was also seen when anti-nucleocapsid IgG, or the combination of both anti-nucleocapsid and anti-spike IgG were used as markers of prior infection. 
medRxiv preprint doi: https://doi.org/10.1101/2020.11.18.20234369; this version posted November 19, 2020. The copyright holder for this preprint (which was not certified by peer review) is the author/funder, who has granted medRxiv a license to display the preprint in perpetuity.

It is made available under a CC-BY 4.0 International license .

The incidence of SARS-CoV-2 infection was inversely associated with baseline anti-spike antibody titres, with higher antibody titres associated with the lowest incidence of positive PCR results. This association extended below the positive threshold for the assay ( 8 million), with likelihood of infection falling above 4 million units. It is likely that some of the individuals with baseline titres below the assay cut-off were previously infected with SARS-CoV-2, and either had low peak antibody titres post infection, or may have been tested later post-infection when antibody titres had declined below the assay threshold. ${ }^{5}$ There was also marginal evidence that rates of PCR-positive results went down with higher antinucleocapsid lgG levels.

Notably two of the four seropositive individuals with subsequent PCR-positive tests had discordant baseline antibody results which were positive on only one of the two IgG assays, with low negative readings on the other assay. Neither had a PCR-confirmed primary infection. It is plausible that one or both had false-positive antibody results which may have occurred for a number of reasons including immunoassay interference. ${ }^{27}$ One of the two developed subsequent symptomatic infection. The two other HCWs seroconverted with both anti-spike and anti-nucleocapsid antibodies detected after an initial illness, one PCR confirmed (albeit with a borderline Ct value). One had a single PCR-positive test, and the other a transient subsequent PCR-positive result, not detected on repeat testing. Both results are consistent with SARS-CoV-2 re-exposure that did not lead to repeat symptoms.

Due to the low number of reinfections in the baseline seropositive group, this study is not currently powered to detect if past seroconversion or current antibody levels are more strongly associated with protection from infection. Similarly, we cannot say how past infection confers protection, whether specifically through the antibodies we measured, or T cell immunity which we did not. Our study is relatively short, following HCWs up for 30 weeks. Ongoing longitudinal measurements of markers of 
medRxiv preprint doi: https://doi.org/10.1101/2020.11.18.20234369; this version posted November 19, 2020. The copyright holder for this preprint (which was not certified by peer review) is the author/funder, who has granted medRxiv a license to display the preprint in perpetuity.

It is made available under a CC-BY 4.0 International license .

humoral and cellular immunity, and PCR testing, will be required to determine the duration and determinants of protection.

HCWs were enrolled in a voluntary testing scheme, with a flexible follow-up schedule, leading to different attendance frequencies. Although asymptomatic PCR testing was offered up to every 2 weeks, HCWs attended less frequently (mean: once every 10-14 weeks), in particular when seropositive.

Therefore, asymptomatic infection is likely to have been under-ascertained in both groups. Additionally, as staff were told their antibody results, this led to 'outcome ascertainment bias', with staff attending less frequently if seropositive. However, a sensitivity analysis suggests the differing attendance rates did not substantially alter our findings. Staff were told explicitly to continue to practice social distancing and follow personal protective equipment guidance irrespective of their antibody results and to attend for testing if they developed fever, new cough or anosmia/ageusia even if they had previously tested PCR or antibody-positive. This is reflected in the similar rates of attendance for symptomatic testing observed if seropositive or seronegative.

Some staff have been lost to follow-up due to terminating employment at our hospitals; however this is likely to have occurred at similar rates in symptomatic and asymptomatic staff. Some PCR-positive results from government symptomatic testing sites may not have been notified to the hospital. Finally, as this is a study of predominantly working age HCWs, further studies are needed to assess postinfection immunity in children, the over 60 s and those with comorbidities, particularly the immunosuppressed.

In summary, this study suggests that prior SARS-CoV-2 infection (defined by either anti-spike or antinucleocapsid antibodies) offers protection from reinfection, in the short term. However, lack of 
medRxiv preprint doi: https://doi.org/10.1101/2020.11.18.20234369; this version posted November 19, 2020. The copyright holder for this preprint (which was not certified by peer review) is the author/funder, who has granted medRxiv a license to display the preprint in perpetuity. It is made available under a CC-BY 4.0 International license .

knowledge regarding the specific effects of each of the range of antibody assays in use, the precise extent of protection and long-term immune responses do not support exempting those positive for antiSARS-CoV-2 antibodies from infection control and public health pandemic control measures at present. Further longitudinal studies, over longer durations, looking at the full range of immune responses to SARS-CoV-2, will be required to determine the full range of correlates and surrogates of protective immunity, the duration of post-infection immunity to reinfection, disease, hospitalisation or death and its impact on onward transmission. This will have important implications for public policy, guiding behaviour and infection control in healthcare settings and beyond. 
medRxiv preprint doi: https://doi.org/10.1101/2020.11.18.20234369; this version posted November 19, 2020. The copyright holder for this preprint (which was not certified by peer review) is the author/funder, who has granted medRxiv a license to display the preprint in perpetuity.

It is made available under a CC-BY 4.0 International license .

\section{Acknowledgements}

We would like to thank all OUH staff who participated in the staff testing programme, and the staff and medical students who ran the programme. This work uses data provided by healthcare workers and collected by the UK's National Health Service as part of their care and support. We thank all the people of Oxfordshire who contribute to the Infections in Oxfordshire Research Database. Research Database Team: L Butcher, H Boseley, C Crichton, DW Crook, DW Eyre, O Freeman, J Gearing (community), R Harrington, K Jeffery, M Landray, A Pal, TEA Peto, TP Quan, J Robinson (community), J Sellors, B Shine, AS Walker, D Waller. Patient and Public Panel: G Blower, C Mancey, P McLoughlin, B Nichols.

\section{Declaration of interests}

DWE declares lecture fees from Gilead, outside the submitted work. RJC is a founder shareholder and consultant to MIROBio, outside the submitted work. No other author has a conflict of interest to declare.

\section{Funding Statement}

This study was funded by the UK Government's Department of Health and Social Care. This work was supported by the National Institute for Health Research Health Protection Research Unit (NIHR HPRU) in Healthcare Associated Infections and Antimicrobial Resistance at Oxford University in partnership with Public Health England (PHE) (NIHR200915), the NIHR Biomedical Research Centre, Oxford, and benefactions from the Huo Family Foundation and Andrew Spokes. The views expressed in this publication are those of the authors and not necessarily those of the NHS, the National Institute for Health Research, the Department of Health or Public Health England. This study is affiliated with Public Health England's Sarscov2 Immunity \& Reinfection EvaluatioN (SIREN) study. 
medRxiv preprint doi: https://doi.org/10.1101/2020.11.18.20234369; this version posted November 19, 2020. The copyright holder for this preprint (which was not certified by peer review) is the author/funder, who has granted medRxiv a license to display the preprint in perpetuity. It is made available under a CC-BY 4.0 International license .

DWE is a Robertson Foundation Fellow and an NIHR Oxford BRC Senior Fellow. SFL is a Wellcome Trust Clinical Research Fellow. DIS is supported by the Medical Research Council (MR/N00065X/1). PCM holds a Wellcome Intermediate Fellowship (110110/Z/15/Z). BDM is supported by the SGC, a registered charity (number 1097737) that receives funds from AbbVie, Bayer Pharma AG, Boehringer Ingelheim, Canada Foundation for Innovation, Eshelman Institute for Innovation, Genome Canada through Ontario Genomics Institute [OGI-055], Innovative Medicines Initiative (EU/EFPIA) [ULTRA-DD grant no. 115766], Janssen, Merck KGaA, Darmstadt, Germany, MSD, Novartis Pharma AG, Pfizer, Sao Paulo Research Foundation-FAPESP, Takeda, and Wellcome. BDM is also supported by the Kennedy Trust for Rheumatology Research. GS is a Wellcome Trust Senior Investigator and acknowledges funding from the Schmidt Foundation. TMW is a Wellcome Trust Clinical Career Development Fellow (214560/Z/18/Z). ASW is an NIHR Senior Investigator. 
medRxiv preprint doi: https://doi.org/10.1101/2020.11.18.20234369; this version posted November 19, 2020. The copyright holder for this preprint (which was not certified by peer review) is the author/funder, who has granted medRxiv a license to display the preprint in perpetuity.

It is made available under a CC-BY 4.0 International license .

\section{Tables}

\begin{tabular}{|c|c|c|c|c|}
\hline & & $\begin{array}{l}\text { Whole cohort } \\
\text { individuals } \\
\quad(n=12219)\end{array}$ & $\begin{array}{l}\text { Anti-spike } \\
\text { seronegative } \\
\text { (n=11052) }\end{array}$ & $\begin{array}{r}\text { Anti-spike } \\
\text { seropositive* } \\
\text { (n=1246) } \\
\text { (includes } 1167 \\
\text { initially sero- } \\
\text { positive HCWs } \\
\text { and } 79 \text { HCWs } \\
\text { who } \\
\text { seroconverted) }\end{array}$ \\
\hline Age (years) & $\begin{array}{l}\text { Median, (IQR) } \\
\text { [Range] }\end{array}$ & $\begin{array}{r}38(29-49) \\
{[16-86]}\end{array}$ & $\begin{array}{r}38(29-49) \\
\quad[16-86]\end{array}$ & $\begin{array}{r}38(29-49) \\
{[17-69]}\end{array}$ \\
\hline $\begin{array}{l}\text { Gender } \\
\text { n (\%) }\end{array}$ & $\begin{array}{l}\text { Female } \\
\text { Male } \\
\text { Other** }\end{array}$ & $\begin{array}{r}9013(73.8 \%) \\
3186(26.1 \%) \\
20(0.2 \%)\end{array}$ & $\begin{array}{r}8188(74.1 \%) \\
2847(25.8 \%) \\
17(0.2 \%)\end{array}$ & $\begin{array}{r}886(71.1 \%) \\
357(28.7 \%) \\
3(0.2 \%)\end{array}$ \\
\hline $\begin{array}{l}\text { Ethnicity } \\
\text { n (\%) }\end{array}$ & $\begin{array}{l}\text { White } \\
\text { Asian } \\
\text { Black } \\
\text { Chinese } \\
\text { Other }\end{array}$ & $\begin{array}{r}8839(72.3 \%) \\
1978(16.2 \%) \\
493(4.0 \%) \\
124(1.0 \%) \\
785(6.4 \%)\end{array}$ & $\begin{array}{r}8142(73.7 \%) \\
1693(15.3 \%) \\
412(3.7 \%) \\
115(1.0 \%) \\
690(6.2 \%)\end{array}$ & $\begin{array}{r}751(60.3 \%) \\
301(24.2 \%) \\
84(6.7 \%) \\
9(0.7 \%) \\
101(8.1 \%)\end{array}$ \\
\hline $\begin{array}{l}\text { Role } \\
\text { n (\%) }\end{array}$ & $\begin{array}{l}\text { Nurse/Healthcare assistant } \\
\text { Doctor } \\
\text { Administrative staff } \\
\text { Medical or nursing student }\end{array}$ & $\begin{array}{r}4406(36.1 \%) \\
1814(14.8 \%) \\
1504(12.3 \%) \\
585(4.8 \%)\end{array}$ & $\begin{array}{r}3857(34.9 \%) \\
1634(14.8 \%) \\
1409(12.7 \%) \\
548(5.0 \%)\end{array}$ & $\begin{array}{r}585(47.0 \%) \\
184(14.8 \%) \\
104(8.3 \%) \\
43(3.5 \%)\end{array}$ \\
\hline
\end{tabular}


medRxiv preprint doi: https://doi.org/10.1101/2020.11.18.20234369; this version posted November 19, 2020. The copyright holder for this preprint (which was not certified by peer review) is the author/funder, who has granted medRxiv a license to display the preprint in perpetuity.

It is made available under a CC-BY 4.0 International license .

\begin{tabular}{|c|c|c|c|c|}
\hline & $\begin{array}{l}\text { Laboratory staff } \\
\text { Physio/OT/Speech therapist } \\
\text { Porter/Domestic } \\
\text { Security/Estates/Catering } \\
\text { Other allied health professionals }\end{array}$ & $\begin{array}{r}438(3.6 \%) \\
378(3.1 \%) \\
368(3.0 \%) \\
263(2.2 \%) \\
2463(20.2 \%)\end{array}$ & $\begin{array}{r}402(3.6 \%) \\
341(3.1 \%) \\
311(2.8 \%) \\
240(2.2 \%) \\
2310(20.9 \%)\end{array}$ & $\begin{array}{r}39(3.1 \%) \\
44(3.5 \%) \\
57(4.6 \%) \\
26(2.1 \%) \\
164(13.2 \%)\end{array}$ \\
\hline $\begin{array}{l}\text { Positive PCR } \\
\text { during } \\
\text { follow up }\end{array}$ & $\begin{array}{l}\text { Total } \\
\text { Symptomatic } \\
\text { Asymptomatic }\end{array}$ & $\begin{array}{r}168(1.4 \%) \\
89 \\
79\end{array}$ & $\begin{array}{r}165(1.5 \%) \\
89\end{array}$ & $\begin{array}{r}3(0.2 \%) \\
0\end{array}$ \\
\hline
\end{tabular}

Table 1. Demographics for 12219 healthcare workers with SARS-CoV-2 anti-spike IgG results.

*Those who started anti-spike antibody negative and then seroconverted $(n=79)$ were allowed to contribute to the analysis twice, once while at risk of infection and antibody negative and then subsequently while antibody positive and at risk of reinfection. Hence the sum of seropositive and seronegative subgroups is greater than the number of individuals in the whole cohort.

**This category includes trans and non-disclosed gender, amalgamated due to small numbers to prevent individuals being identified. 


\begin{tabular}{|c|c|c|c|c|c|c|}
\hline & $\begin{array}{l}\text { Unadjusted } \\
\text { incidence } \\
\text { rate ratio }\end{array}$ & $\begin{array}{r}\text { Unadjusted } \\
95 \% \mathrm{Cl}\end{array}$ & $\begin{array}{r}\text { Unadjusted } \mathbf{P} \\
\text { value }\end{array}$ & $\begin{array}{l}\text { Adjusted } \\
\text { incidence } \\
\text { rate ratio }\end{array}$ & $\begin{array}{l}\text { Adjusted } \\
995 \% \mathrm{Cl}\end{array}$ & $\begin{array}{r}\text { Adjusted } \mathbf{P} \\
\text { value }\end{array}$ \\
\hline $\begin{array}{l}\text { Anti-spike } \\
\text { IgG negative }\end{array}$ & 1.00 & & & 1.00 & & \\
\hline $\begin{array}{l}\text { Anti-spike } \\
\text { IgG positive }\end{array}$ & 0.24 & $0.08,0.76$ & 0.015 & 0.25 & $0.08,0.80$ & 0.019 \\
\hline April-June & 1.00 & & & 1.00 & & \\
\hline July & 0.17 & $0.08,0.37$ & $<0.001$ & 0.18 & $0.08,0.39$ & $<0.001$ \\
\hline August & 0.18 & $0.09,0.38$ & $<0.001$ & 0.20 & $0.09,0.41$ & $<0.001$ \\
\hline September & 0.25 & $0.13,0.48$ & $<0.001$ & 0.27 & $0.14,0.52$ & $<0.001$ \\
\hline October & 0.79 & $0.52,1.19$ & 0.26 & 0.86 & $0.57,1.30$ & 0.48 \\
\hline November & 1.71 & $1.16,2.51$ & 0.006 & 1.87 & $1.27,2.75$ & 0.001 \\
\hline $\begin{array}{l}\text { Gender, } \\
\text { Female }\end{array}$ & 1.00 & & & 1.00 & & \\
\hline $\begin{array}{l}\text { Gender, } \\
\text { Male }\end{array}$ & 1.01 & $0.72, .143$ & 0.93 & 1.03 & $0.73,1.46$ & 0.85 \\
\hline Age* & & & & & & \\
\hline
\end{tabular}

Table 2. Estimated incidence rate ratios by anti-spike IgG antibody status as a binary variable adjusting for age, gender and incidence by calendar month. $20 \mathrm{HCWs}$ identifying as Trans or with a non-disclosed gender are not shown, as there were zero PCR-positive results in these individuals, 17 of whom were seronegative and 3 of whom were seropositive. *Age was fitted as a continuous variable with a 5 knot spline (Supplementary Figure S2). 
medRxiv preprint doi: https://doi.org/10.1101/2020.11.18.20234369; this version posted November 19, 2020. The copyright holder for this preprint (which was not certified by peer review) is the author/funder, who has granted medRxiv a license to display the preprint in perpetuity.

It is made available under a CC-BY 4.0 International license .

\section{Figure legends}

Figure 1. Observed and estimated incidence of SARS-CoV-2 positive PCR results by baseline anti-spike IgG antibody status. Panel A shows the observed cases per 10,000 HCW days at risk. The cases in seronegative staff are shown in red and seropositive staff in blue. The total number of HCW days at risk by month are shown in red and blue text above the $x$ axis. Panel $B$ shows the estimated daily incidence of SARS-CoV-2 positive PCR results per 10,000 HCW days at risk, by baseline antibody status ( $95 \%$ confidence intervals are indicated by the coloured ribbons). The Poisson regression model is adjusted for age (using a 5 knot spline, similar to Supplementary Figure S2), gender and calendar time fitted as continuous, using a 5 knot natural cubic spline with default knot positions.

Figure 2. Estimated daily incidence by baseline anti-trimeric spike and anti-nucleocapsid spike IgG antibody titre. Panel A shows the estimated daily incidence per 10,000 healthcare workers, by antitrimeric spike lgG titre (Oxford immunoassay, p-value vs no trend $=0.013$ ), using a 3 knot spline (number of knots chosen using the Akaike information criterion [AIC]). Panel B shows the estimated daily incidence per 10,000 healthcare workers by anti-nucleocapsid IgG titre (Abbott SARS-CoV-2 IgG assay; $p=0.08$ ), linear model plotted as lowest AIC. The models used in both panels adjust for age (set at the median age, 38 years), gender (set as female) and calendar month (set as October 2020). The light blue ribbon shows the $95 \%$ confidence interval, and the vertical dotted line indicates the assay positive cut-off.

Figure 3. Antibody trajectories and PCR results for four seropositive individuals with subsequent positive PCR results. Three HCWs became PCR-positive having been anti-spike IgG seropositive (two also positive for anti-nucleocapsid $\lg G$ ), and one having been anti-nucleocapsid IgG positive alone. The $x$ axis shows time since the first episode, this is defined as date of first positive PCR, onset of symptoms if 
medRxiv preprint doi: https://doi.org/10.1101/2020.11.18.20234369; this version posted November 19, 2020. The copyright holder for this preprint (which was not certified by peer review) is the author/funder, who has granted medRxiv a license to display the preprint in perpetuity. It is made available under a CC-BY 4.0 International license .

symptomatic and no PCR performed, or first attendance at clinic if asymptomatic and no PCR performed during presumed index infection. Antibody trajectories are shown by lines with circular points (blue = anti-nucleocapsid IgG, lilac = anti-spike IgG), PCR results are shown in green (negative) and red (positive). Assay thresholds are shown by dotted lines; anti-spike IgG (positive $\geq 8$ million (lilac dotted line)) assays and anti-nucleocapsid IgG (positive $\geq 1.4$ (blue dotted line). 


\section{References}

1. Plotkin, S. A. Vaccines: correlates of vaccine-induced immunity. Clin. Infect. Dis. 47, 401-409 (2008).

2. Seow, J. et al. Longitudinal observation and decline of neutralizing antibody responses in the three months following SARS-CoV-2 infection in humans. Nat Microbiol (2020) doi:10.1038/s41564-02000813-8.

3. Robbiani, D. F. et al. Convergent antibody responses to SARS-CoV-2 in convalescent individuals. Nature vol. 584 437-442 (2020).

4. Gudbjartsson, D. F. et al. Humoral Immune Response to SARS-CoV-2 in Iceland. N. Engl. J. Med. 383, 1724-1734 (2020).

5. Lumley, S. F. et al. The duration, dynamics and determinants of SARS-CoV-2 antibody responses in individual healthcare workers. Infectious Diseases (except HIV/AIDS) (2020) doi:10.1101/2020.11.02.20224824.

6. Long, Q.-X. et al. Clinical and immunological assessment of asymptomatic SARS-CoV-2 infections. Nat. Med. 26, 1200-1204 (2020).

7. Muecksch, F. et al. Longitudinal analysis of serology and neutralizing antibody levels in COVID19 convalescents. J. Infect. Dis. (2020) doi:10.1093/infdis/jiaa659.

8. To, K. K.-W. et al. Temporal profiles of viral load in posterior oropharyngeal saliva samples and serum antibody responses during infection by SARS-CoV-2: an observational cohort study. Lancet Infect. Dis. 20, 565-574 (2020).

9. GeurtsvanKessel, C. H. et al. An evaluation of COVID-19 serological assays informs future diagnostics and exposure assessment. Nat. Commun. 11, 3436 (2020).

10. Wajnberg, A. et al. Robust neutralizing antibodies to SARS-CoV-2 infection persist for months. Science (2020) doi:10.1126/science.abd7728.

11. Tillett, R. L. et al. Genomic evidence for reinfection with SARS-CoV-2: a case study. Lancet Infect. 
medRxiv preprint doi: https://doi.org/10.1101/2020.11.18.20234369; this version posted November 19, 2020. The copyright holder for this preprint (which was not certified by peer review) is the author/funder, who has granted medRxiv a license to display the preprint in perpetuity. It is made available under a CC-BY 4.0 International license .

Dis. (2020) doi:10.1016/S1473-3099(20)30764-7.

12. Van Elslande, J. et al. Symptomatic SARS-CoV-2 reinfection by a phylogenetically distinct strain. Clin. Infect. Dis. (2020) doi:10.1093/cid/ciaa1330.

13. Prado-Vivar, B. et al. COVID-19 Re-Infection by a Phylogenetically Distinct SARS-CoV-2 Variant, First Confirmed Event in South America. (2020) doi:10.2139/ssrn.3686174.

14. To, K. K.-W. et al. COVID-19 re-infection by a phylogenetically distinct SARS-coronavirus-2 strain confirmed by whole genome sequencing. Clin. Infect. Dis. (2020) doi:10.1093/cid/ciaa1275.

15. Gupta, V. et al. Asymptomatic reinfection in two healthcare workers from India with genetically distinct SARS-CoV-2. Clin. Infect. Dis. (2020) doi:10.1093/cid/ciaa1451.

16. Walker, A. S. et al. Viral load in community SARS-CoV-2 cases varies widely and temporally. medRxiv (2020).

17. Mumoli, N., Vitale, J. \& Mazzone, A. Clinical immunity in discharged medical patients with COVID19. Int. J. Infect. Dis. 99, 229-230 (2020).

18. Zhang, K., Lau, J. Y.-N., Yang, L. \& Ma, Z.-G. SARS-CoV-2 reinfection in two patients who have recovered from COVID-19. Prec Clin Med doi:10.1093/pcmedi/pbaa031.

19. Gousseff, M. et al. Clinical recurrences of COVID-19 symptoms after recovery: Viral relapse, reinfection or inflammatory rebound? J. Infect. 81, 816-846 (2020).

20. European Centre for Disease Prevention and Control. Re-infection and viral shedding - threat assessment brief. ECDC (2020).

21. Addetia, A. et al. Neutralizing Antibodies Correlate with Protection from SARS-CoV-2 in Humans during a Fishery Vessel Outbreak with a High Attack Rate. J. Clin. Microbiol. 58, (2020).

22. Eyre, D. W. et al. Differential occupational risks to healthcare workers from SARS-CoV-2 observed during a prospective observational study. Elife 9, (2020).

23. National SARS-CoV-2 Serology Assay Evaluation Group. Performance characteristics of five 
medRxiv preprint doi: https://doi.org/10.1101/2020.11.18.20234369; this version posted November 19, 2020. The copyright holder for this preprint (which was not certified by peer review) is the author/funder, who has granted medRxiv a license to display the preprint in perpetuity. It is made available under a CC-BY 4.0 International license .

immunoassays for SARS-CoV-2: a head-to-head benchmark comparison. Lancet Infect. Dis. (2020) doi:10.1016/S1473-3099(20)30634-4.

24. Adams, E. R. et al. Antibody testing for COVID-19: A report from the National COVID Scientific Advisory Panel. Wellcome Open Res 5, 139 (2020).

25. Cento, V. et al. Persistent positivity and fluctuations of SARS-CoV-2 RNA in clinically-recovered COVID-19 patients. J. Infect. 81, e90-e92 (2020).

26. Chu, C. M. et al. Duration of RT-PCR positivity in severe acute respiratory syndrome. Eur. Respir. J. 25, 12-14 (2005).

27. Ward, G., Simpson, A., Boscato, L. \& Hickman, P. E. The investigation of interferences in immunoassay. Clin. Biochem. 50, 1306-1311 (2017). 
A

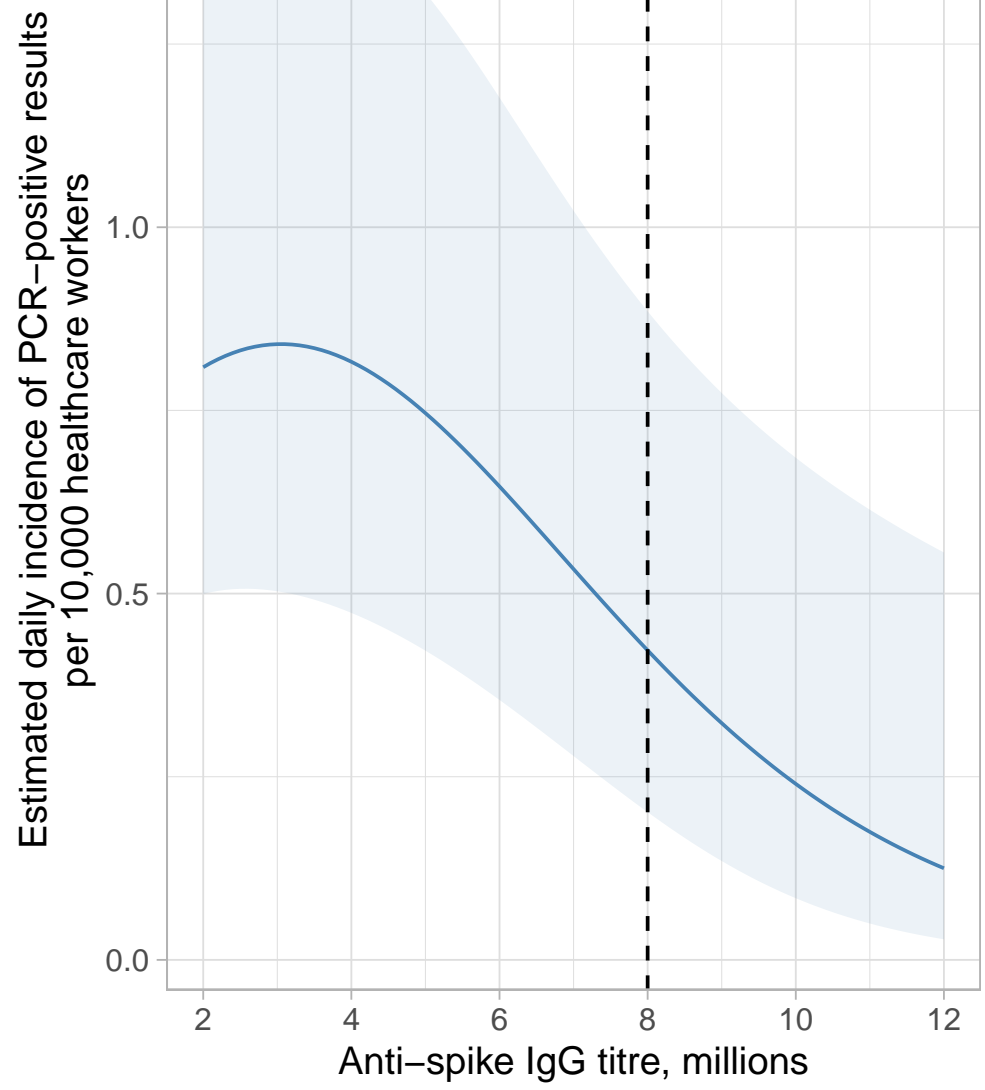

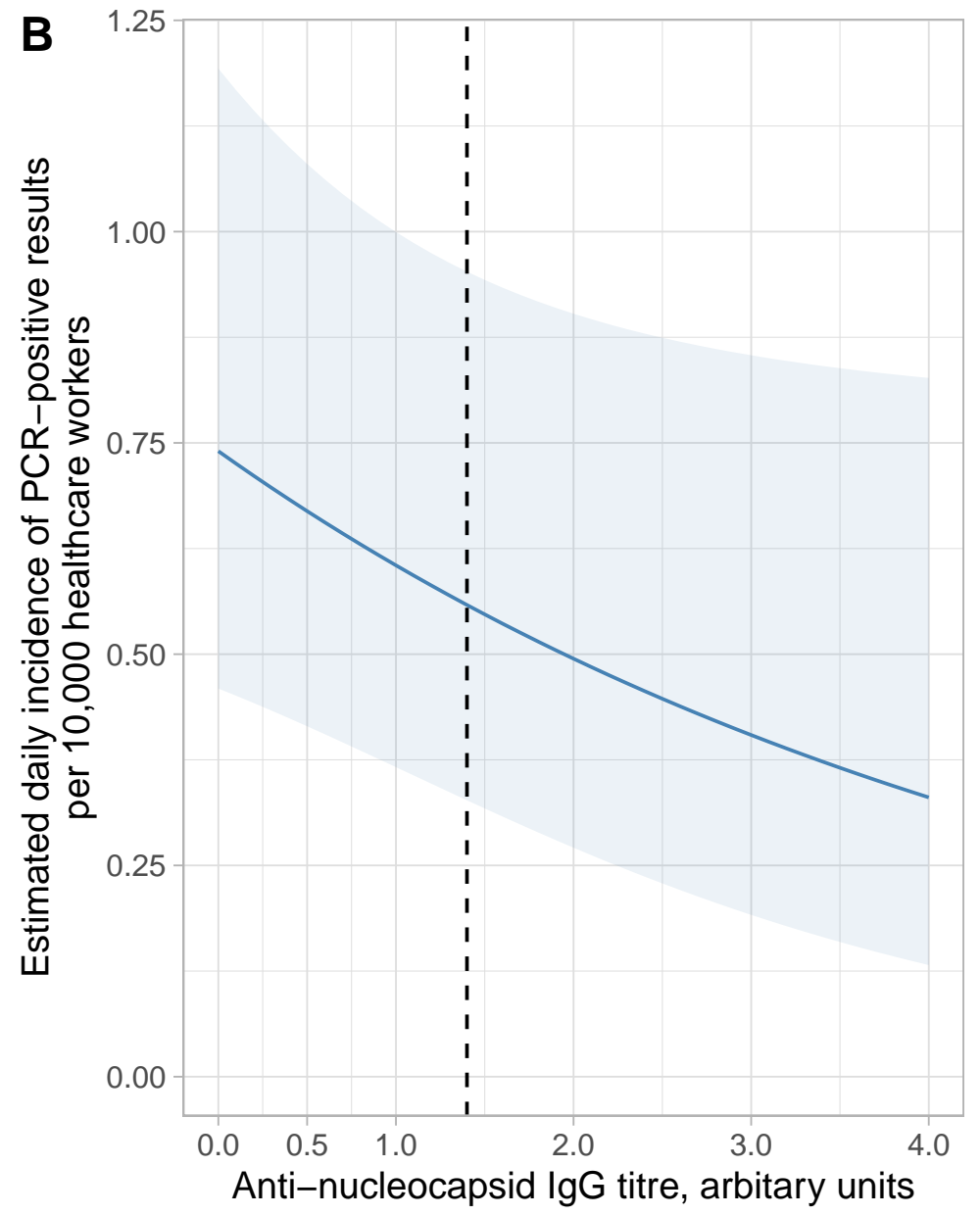


HCW 1

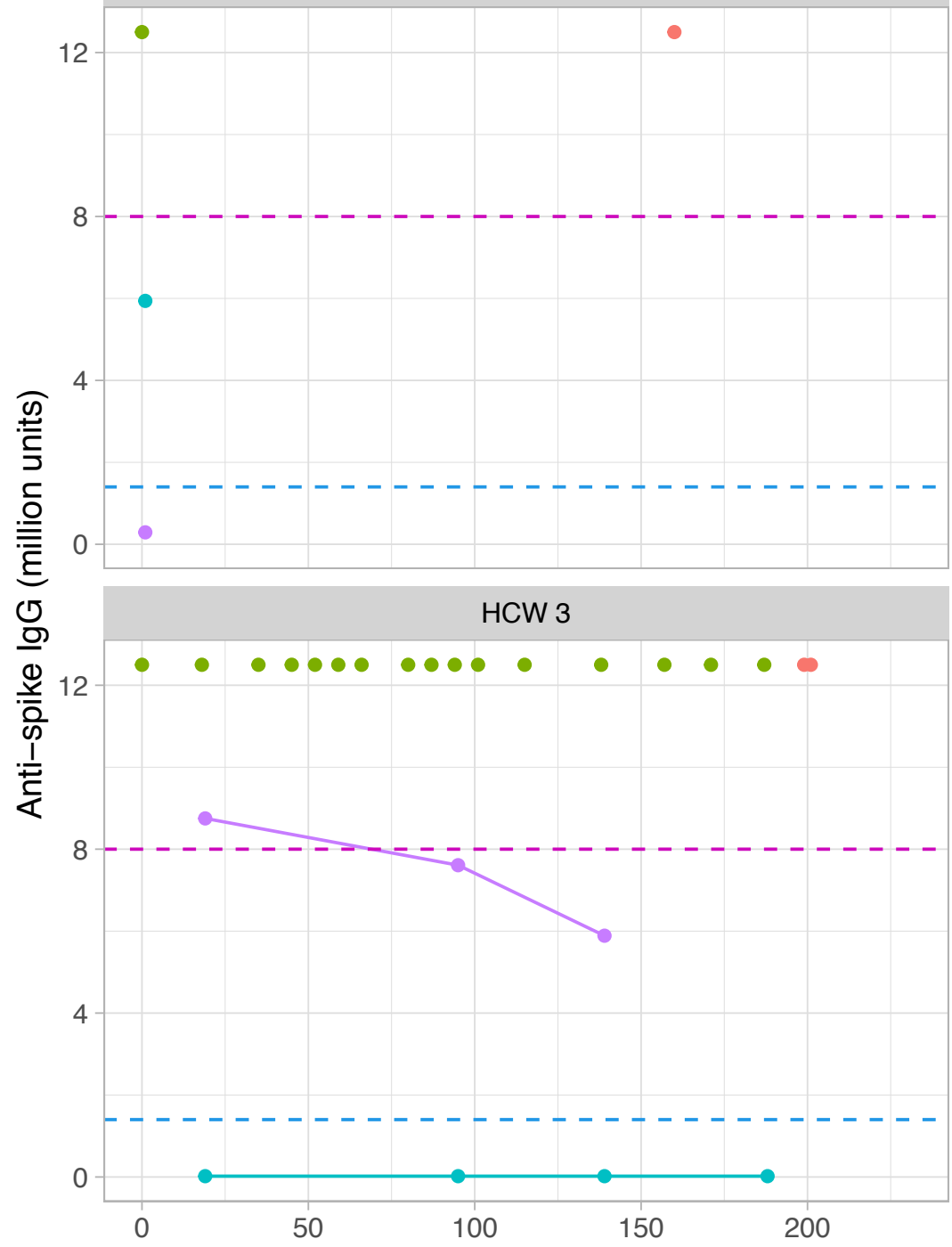

HCW 2

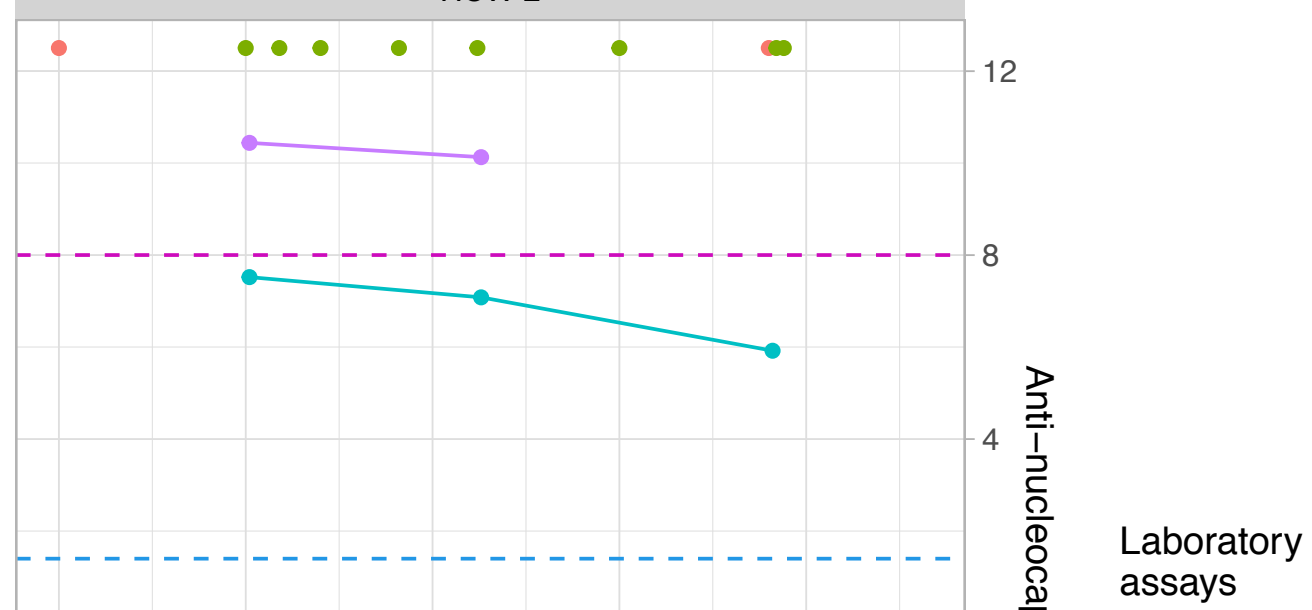

HCW 4

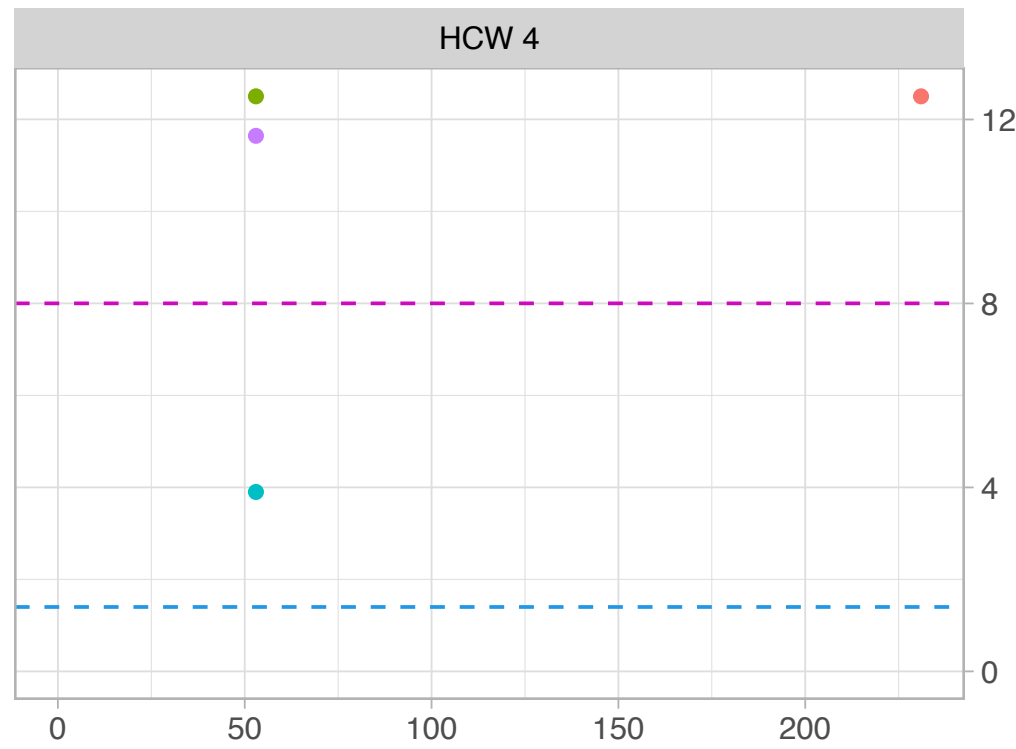

- PCR positive

- PCR negative

$\rightarrow$ Anti-nucleocapsid IgG

$\rightarrow$ Anti-spike IgG 